\title{
Papers
}

\section{Treatment of ocular hypertension and open angle glaucoma: meta-analysis of randomised controlled trials}

\author{
Philip C Maier, Jens Funk, Guido Schwarzer, Gerd Antes, Yngve T Falck-Ytter
}

\begin{abstract}
Objective Open angle glaucoma is one of the most common causes of blindness in industrialised nations. Treatments to lower ocular pressure are widely used in glaucoma prevention and treatment, despite conflicting evidence.

Design We performed meta-analyses to reassess the effectiveness of pressure lowering treatment to delay the development of glaucoma in ocular hypertension, as well as progression of manifest open angle glaucoma.

Data sources Medline, Embase, and the Cochrane Library.

Selection of studies Eligible studies were randomised controlled trials with a concurrent untreated control group and information on time to glaucomatous changes to visual field and optic disc. Trial reports were reviewed independently by two investigators in an unblinded standardised manner.

Results Meta-analysis of trials in ocular hypertension showed a significant preventive effect of reducing intraocular pressure on progression to glaucoma (hazard ratio $0.56,95 \%$ confidence interval 0.39 to $0.81, \mathrm{P}=0.01$; number needed to treat 12 ). Pooled data of studies in manifest glaucoma showed a significant delay of visual field deterioration $(0.65,0.49$ to 0.87 , $\mathrm{P}=0.003 ; \mathrm{NNT}=7$ ), with subgroup analysis showing a larger effect in patients with raised pressure and a reduced effect in normal tension glaucoma (subgroup comparison: not significant).

Conclusions Lowering intraocular pressure in patients with ocular hypertension or manifest glaucoma is beneficial in reducing the risk of visual field loss in the long term.
\end{abstract}

\section{Introduction}

Glaucoma is one of the most common causes of blindness in industrialised nations, with prevalences between $1 \%$ and $3 \%{ }^{1}$ This primary chronic disease is an optic neuropathy characterised by an acquired loss of retinal ganglion cells and atrophy of the optic nerve. As increased intraocular pressure may or may not be present (as seen in patients with normal tension glaucoma who represent about $15-40 \%$ of all patients with open angle glaucoma ${ }^{2}$ ), the definition of open angle glaucoma has changed so that the diagnosis is now based only on glaucomatous visual field defects or typical changes of the optic disc (table 1). However, raised intraocular pressure remains an important risk factor for the development or the progression of primary open angle glaucoma. ${ }^{3}$ Remarkably, patients in general do not have symptoms from glaucoma until large, irreversible visual field defects have occurred. Interventions at an early stage of the disease therefore promise to be most effective. Ideally, this would be at a presymptomatic stage-for example, in patients with ocular

\begin{tabular}{|c|c|c|c|}
\hline \multirow[b]{2}{*}{ Pathology } & \multirow[b]{2}{*}{$\begin{array}{l}\text { Ocular } \\
\text { hypertension }\end{array}$} & \multicolumn{2}{|l|}{ Open angle glaucoma } \\
\hline & & $\begin{array}{l}\text { Primary open angle } \\
\text { glaucoma }\end{array}$ & $\begin{array}{l}\text { Normal tension } \\
\text { glaucoma }\end{array}$ \\
\hline $\begin{array}{l}\text { Raised intraocular } \\
\text { pressure }\end{array}$ & Yes & Yes & No \\
\hline $\begin{array}{l}\text { Optic disc changes or } \\
\text { visual field defects, or } \\
\text { both }\end{array}$ & No & Yes & Yes \\
\hline Symptoms & No & $<50 \%$ at diagnosis & $<50 \%$ at diagnosis \\
\hline
\end{tabular}

hypertension (increased intraocular pressure without any glaucomatous changes of the optic disc or visual field defects), with effective therapy preventing any progression to manifest glaucoma. However, because most people with ocular hypertension will not develop glaucoma ${ }^{4}$ and a prior meta-analysis was unable to show a significant effect, ${ }^{5}$ preventive therapy has been controversial. If early visual field loss has occurred or the optic disc has been classified as having typical glaucomatous changes then treatment to lower the intraocular pressure is initiated in virtually all patients. Since this approach includes patients with normal tension glaucoma, a relative, rather than absolute, reduction of intraocular pressure (for example, 20\%) is the initial target.

The primary objective was to review systematically the literature with regard to the effectiveness of treatment of ocular hypertension and open angle glaucoma (both primary open angle glaucoma and normal tension glaucoma).

\section{Methods}

Databases searched included the Cochrane Central Register of Controlled Trials (2004), Medline (1966-2004), and Embase (1974-2004). We searched other databases for guidelines and health technology assessment reports covering glaucoma. We also searched reference lists of relevant articles for additional trials and used the Science Citation Index to search for articles that cited the included studies. For relevant ongoing trials we contacted investigators and experts. The search was not restricted to specific languages or years of publication.

\section{Search strategy}

For the search in Medline (Ovid) we used the following search terms (the strategy was MESH term as well as textword based): "Glaucoma/pc, dt, su, th"; "exp Glaucoma, Open-Angle/pc, dt, su, th"; "ocular hypertension/pc, dt, su, th"; "randomised controlled trial.pt."; "glaucoma\$.tw"; "ocular hypertensi\$.tw"; "rando\$.tw". 
Potentially relevant reports identified and screened by title/abstract for retrieval $(n=1213)$

Reports excluded $(n=1202)$

Reasons: No randomised controlled trial, less than one year follow-up, no untreated control group, only reduction of intraocular pressure as end point

Reports retrieved for more detailed evaluation $(\mathrm{n}=11)$ (8 ocular hypertension, 3 open angle glaucoma)

Ocular hypertension trials excluded $(n=3)$ Reasons: Short follow-up, randomisation unclear, no real control group (compared eyes, not patients)

Open angle glaucoma trials excluded $(n=1)$ Reasons: Data not extractable

Appropriate trials included in meta-analysis of ocular hypertension $(n=5)$

Appropriate trials included in meta-analysis of open angle glaucoma $(n=2)$

Fig 1 Trial flow shows the number of trials screened, retrieved for evaluation, and included in the analysis

\section{Study selection}

According to the prespecified protocol, we included only randomised controlled trials of pressure lowering treatment (medical and surgical) with a concurrent untreated control group and appropriate end points, such as glaucomatous visual field defects or glaucomatous changes to the optic disc. We excluded inappropriate study designs, such as intraocular pressure reduction as the only end point or sole reliance on historical controls, as well as follow-up of less than one year.

\section{Description of studies}

Literature searches of the bibliographic databases yielded 1213 reports, which consisted mostly of studies comparing one drug with another. Two authors (PCM and YTF-Y) reviewed retrieved abstracts independently in an unblinded standardised manner. We then obtained and critically appraised relevant articles and extracted data independently. We resolved disagreements by discussion. Five studies included a total of 2326 patients with ocular hypertension who were randomly assigned to various pressure lowering eye drops compared with placebo. ${ }^{6-10}$ Two studies in patients with manifest glaucoma (total: 400) used either eye drops or surgical approaches to lower intraocular pressure. ${ }^{11-13}$ We found no unpublished trials. Figure 1 gives further details on numbers of included and excluded studies. For details on study designs see table 2 for excluded studies, and tables 3 and 4 for studies included in the meta-analysis on ocular hypertension and glaucoma, respectively.

\section{Data extraction and analysis}

We used a standardised form to extract the following data from the methodologically adequate randomised controlled trials: randomisation procedure, allocation concealment, masking, type of interventions, participant flow, sample size, length of follow-up, numbers of patients randomised, numbers analysed, outcome data and estimation, and loss to follow-up. For the meta-analysis we reassessed the numbers of patients originally described as developing the outcome "glaucoma" to include only patients with unequivocal glaucomatous changes to the visual field or optic disc, according to current definition of glaucoma. We ignored older outcome definitions, such as disc haemorrhage, "very high" but asymptomatic intraocular pressure elevation alone, which yielded a more conservative estimate since such pressure readings were more common in the control groups. We extracted information on the time to definite visual field deteriorations and optic disc changes compatible with open angle glaucoma, rather than binary data at one or two fixed points in time. This allowed us to use the study data to the fullest by performing meta-analyses of time to event data using the hazard ratio. The hazard ratio then represents the relative risk of development or worsening of glaucoma during treatment compared with the control group. If the hazard ratio was not reported and data on individual patients were not available we calculated the hazard ratio by using methods described by Parmar et al. ${ }^{14}$ We performed separate meta-analyses for ocular hypertension and for open angle glaucoma, using the DerSimonian and Laird random effects model in $\mathrm{R},{ }^{15}$ as well as predefined subgroup analysis of normal tension glaucoma compared with

\begin{tabular}{|c|c|c|c|c|}
\hline Study & Study design & Outcome & Comment & Reason \\
\hline Shin et al $1976^{18}$ & $\begin{array}{l}\text { Randomised controlled trial, epinephrine } \\
\text { treatment ( } 1-2 \% \text { twice daily) } v \\
\text { observation in ocular hypertension } \\
\text { Randomised: } 38 \text { eyes of patients } \\
\text { Duration: } 1-5 \text { years } \\
\text { End points: deterioration of visual field or } \\
\text { optic disc }\end{array}$ & $\begin{array}{l}\text { After } 1-5 \text { years follow-up, } 2 \text { treated } v 11 \\
\text { control patients reached end points } \\
(\mathrm{P}<0.01)\end{array}$ & $\begin{array}{l}\text { Significant treatment effect of reduction } \\
\text { of intraocular pressure. Effect of } \\
\text { epinephrine on control eye possible. No } \\
\text { data about dropout rate, no definition of } \\
\text { ocular hypertension, no analysis by } \\
\text { intention to treat }\end{array}$ & $\begin{array}{l}\text { No true control group } \\
\text { (compared eyes and not } \\
\text { patients) }\end{array}$ \\
\hline Kitazawa et al $1981^{19}$ & $\begin{array}{l}\text { Controlled trial, timolol treatment } \\
(0.25-0.5 \% \text { bid) } v \text { placebo in ocular } \\
\text { hypertension } \\
\text { Included: } 52 \text { patients } \\
\text { Duration: } 1 \text { year } \\
\text { Endpoints: deterioration of visual field }\end{array}$ & $\begin{array}{l}\text { After } 1 \text { year follow-up, } 1 \text { treated } v 2 \\
\text { control patients reached end points } \\
(P>0.1)\end{array}$ & $\begin{array}{l}\text { Non-significant treatment effect. No } \\
\text { analysis by intention to treat, no data } \\
\text { about dropout rate }\end{array}$ & $\begin{array}{l}\text { Probably no randomisation } \\
\text { Short follow-up }\end{array}$ \\
\hline Kass et al $1989^{20}$ & $\begin{array}{l}\text { Double blind randomised controlled trial, } \\
\text { timolol ( } 0.25 \% \text { twice daily) in one eye } v \\
\text { no treatment in the other in } 62 \text { patients } \\
\text { with ocular hypertension } \\
\text { Duration: } 5 \text { years } \\
\text { End points: Visual field deterioration, disc } \\
\text { haemorrhage, glaucomatous disc }\end{array}$ & $\begin{array}{l}\text { After } 5 \text { years follow-up, } 4 \text { treated eyes } v \\
10 \text { untreated eyes reached end points } \\
(P<0.05)\end{array}$ & $\begin{array}{l}\text { Beneficial effect on deterioration of visual } \\
\text { field. Effect of timolol on control eye } \\
\text { possible. High dropout rate of }>20 \%\end{array}$ & $\begin{array}{l}\text { No true control group } \\
\text { (compared eyes and not } \\
\text { patients) }\end{array}$ \\
\hline Holmin et al $1988^{21}$ & $\begin{array}{l}\text { Randomised controlled trial, various } \\
\text { medications } v \text { observation in primary } \\
\text { open angle glaucoma. } \\
\text { Randomised: } 16 \text { patients } \\
\text { Duration: } 3 \text { years } \\
\text { End point: Deterioration of visual field }\end{array}$ & $\begin{array}{l}\text { Per protocol: regression analysis showed } \\
\text { no significant difference between treated } \\
\text { and untreated patients }\end{array}$ & $\begin{array}{l}\text { Missing data on dropout rate and } \\
\text { numbers of patients who reached end } \\
\text { points }\end{array}$ & $\begin{array}{l}\text { Necessary data could not be } \\
\text { extracted for analysis }\end{array}$ \\
\hline
\end{tabular}


Table 3 Studies included in the meta-analysis on ocular hypertension (reported data only)

\begin{tabular}{|c|c|c|c|}
\hline Study & Study design & Outcome & Comment \\
\hline $\begin{array}{l}\text { Epstein et al } \\
1989^{6}\end{array}$ & $\begin{array}{l}\text { Randomised controlled } \\
\text { trial, timolol }(0.5 \% \\
\text { twice daily) } v \text { no } \\
\text { treatment in } 107 \\
\text { patients with ocular } \\
\text { hypertension } \\
\text { Duration: } 56 \text { months } \\
\text { End points: visual field } \\
\text { defects, intraocular } \\
\text { pressure }>32 \mathrm{~mm} \mathrm{Hg} \text {, } \\
\text { glaucomatous disc }\end{array}$ & $\begin{array}{l}\text { Intention to treat } \\
\text { analysis: } 9 \text { of } 53 \\
\text { patients } \vee 17 \text { of } 54 \\
\text { controls reached end } \\
\text { point }(P=0.07, \text { log rank } \\
\text { test); } 6 \vee 10 \text { failures } \\
\text { owing to visual field } \\
\text { defects or } \\
\text { glaucomatous disc } \\
\text { ( } P=0.24 \text {, log rank test) }\end{array}$ & $\begin{array}{l}\text { Tendency of beneficial } \\
\text { effect. Dropout rate } \\
>20 \%\end{array}$ \\
\hline $\begin{array}{l}\text { Schulzer et al } \\
1991^{7}\end{array}$ & $\begin{array}{l}\text { Randomised controlled } \\
\text { trial, timolol } \\
(0.25-0.5 \% \text { twice daily) } \\
v \text { no treatment in } 143 \\
\text { patients with ocular } \\
\text { hypertension } \\
\text { Duration: } 6 \text { years } \\
\text { End points: visual field } \\
\text { defects or } \\
\text { glaucomatous disc, } \\
\text { disc haemorrhage }\end{array}$ & $\begin{array}{l}\text { Intention to treat } \\
\text { analysis: } 20 \text { of } 67 \\
\text { patients } v 22 \text { of } 70 \\
\text { controls reached end } \\
\text { point (difference not } \\
\text { significant) }\end{array}$ & $\begin{array}{l}\text { No protective treatment } \\
\text { effect observed with } \\
\text { pressure reduction. } \\
\text { Dropout rate }>20 \%\end{array}$ \\
\hline Heijl et al $2000^{8}$ & $\begin{array}{l}\text { Double blind, } \\
\text { randomised controlled } \\
\text { trial, timolol ( } 0.5 \% \\
\text { twice daily) } v \text { no } \\
\text { treatment in } 90 \\
\text { patients with ocular } \\
\text { hypertension plus risk } \\
\text { factors } \\
\text { Duration: } 10 \text { years } \\
\text { (post-study analysis } \\
\text { after } 17 \text { years) } \\
\text { End point: visual field } \\
\text { defects or } \\
\text { glaucomatous disc }\end{array}$ & $\begin{array}{l}\text { Intention to treat } \\
\text { analysis: } 7 \text { of } 46 \\
\text { patients } v 15 \text { of } 44 \\
\text { controls reached end } \\
\text { point after } 10 \text { years } \\
(\mathrm{P}=0.07, \text { log rank test) }\end{array}$ & $\begin{array}{l}\text { Tendency of beneficial } \\
\text { effect. In the treatment } \\
\text { group, intraocular } \\
\text { pressure was higher in } \\
\text { patients who reached } \\
\text { the end point. Dropout } \\
\text { rate }>20 \%\end{array}$ \\
\hline Kass et al $2002^{9}$ & $\begin{array}{l}\text { Randomised controlled } \\
\text { trial, various } \\
\text { medications (titrated to } \\
\text { lower intraocular } \\
\text { pressure } 20 \% \text { or }<24 \\
\mathrm{~mm} \mathrm{Hg} \text { v observation } \\
\text { in ocular hypertension } \\
\text { Duration: } 5 \text { years } \\
\text { End points: visual field } \\
\text { defects or } \\
\text { glaucomatous disc }\end{array}$ & $\begin{array}{l}\text { Intention to treat } \\
\text { analysis: } 36 \text { of } 817 \\
\text { treated } v 89 \text { of } 819 \\
\text { control patients } \\
\text { reached end point } \\
\text { (hazard ratio } 0.40,95 \% \\
\text { Cl } 0.27 \text { to } 0.59, \\
\mathrm{P}<0.0001 \text { ) }\end{array}$ & $\begin{array}{l}\text { Protective or preventive } \\
\text { treatment effect of } \\
\text { topical or medical } \\
\text { reduction of intraocular } \\
\text { pressure. } 3328 \text { patients } \\
\text { screened, } 1636 \\
\text { patients included. } \\
\text { Dropout rate about } \\
14 \%\end{array}$ \\
\hline $\begin{array}{c}\text { Kamal et al } \\
2003^{10}\end{array}$ & $\begin{array}{l}\text { Randomised controlled } \\
\text { trial, betaxolol twice } \\
\text { daily } v \text { placebo in } 356 \\
\text { patients with ocular } \\
\text { hypertension } \\
\text { Duration: } 6 \text { years } \\
\text { End point: visual field } \\
\text { defects }\end{array}$ & $\begin{array}{l}\text { Intention to treat } \\
\text { analysis: } 15 \text { of } 182 \\
\text { treated } v 18 \text { of } 174 \\
\text { control patients } \\
\text { reached end point } \\
(\mathrm{P}=0.25)\end{array}$ & $\begin{array}{l}\text { No significant } \\
\text { preventive effect of } \\
\text { topical reduction of } \\
\text { intraocular pressure. } \\
\text { Dropout rate } 28 \%\end{array}$ \\
\hline
\end{tabular}

increased pressure glaucoma. We assessed heterogeneity by inspecting the forest plot, the $\chi^{2}$ test as well as the $\mathrm{I}^{2}$ statistic $^{16}$ for heterogeneity. Sensitivity analysis included using the random and fixed effects model as well as a pre-defined subgroup analysis of elevated and normal tension glaucoma. We used methods described by Altman et $\mathrm{al}^{17}$ to calculate the number needed to treat to prevent the first glaucomatous visual field defect in patients with ocular hypertension and glaucoma progression in patients with open angle glaucoma within five years after treatment onset. ${ }^{17}$

\section{Results}

When we looked at the treatment of patients with ocular hypertension alone, we found earlier trials of treatment for intraocular pressure reduction difficult to interpret because of poor study design (for example, an inadequate control group), small sample size, and short follow-up. ${ }^{18}{ }^{19}$ Six studies ${ }^{6-10} 20$ showed major
Table 4 Studies included in meta-analysis on open angle glaucoma (both primary open angle glaucoma and normal tension glaucoma (reported data only))

\begin{tabular}{|c|c|c|c|}
\hline Study & Study design & Outcome & Comment \\
\hline $\begin{array}{l}\text { Heijl et al } 2002^{11} 12 \\
\text { (early manifest } \\
\text { glaucoma trial) }\end{array}$ & $\begin{array}{l}\text { Randomised } \\
\text { controlled trial, laser } \\
\text { trabeculoplasty, } \\
\text { betaxolol ( } 5 \mathrm{mg} / \mathrm{ml}, \\
\text { twice daily) and } \\
\text { latanoprost ( } 50 \mu \mathrm{g} / \mathrm{ml} \text {, } \\
\text { once daily) when } \\
\text { intraocular pressure } \\
>25 \mathrm{~mm} \mathrm{Hg} \text { in treated } \\
v \text { observation in } \\
\text { primary open angle } \\
\text { glaucoma or normal } \\
\text { tension glaucoma } \\
\text { Randomised: } 255 \\
\text { patients } \\
\text { Duration: } 6 \text { years } \\
\text { End point: } \\
\text { deterioration of visual } \\
\text { field or optic disc }\end{array}$ & $\begin{array}{l}\text { Intention to treat } \\
\text { analysis: } 58 \text { of } 129 \\
\text { treated } v 78 \text { of } 126 \\
\text { control patients } \\
\text { reached end point } \\
(P=0.007 \text {, log rank } \\
\text { test) }\end{array}$ & $\begin{array}{l}\text { Significant protective } \\
\text { treatment effect of } \\
\text { reduction of } \\
\text { intraocular pressure. } \\
\text { Dropout rate about } \\
11 \%\end{array}$ \\
\hline $\begin{array}{l}\text { Collaborative } \\
\text { Normal Tension } \\
\text { Glaucoma Study } \\
\text { Group } 1998^{13}\end{array}$ & $\begin{array}{l}\text { Randomised } \\
\text { controlled trial, } \\
\text { medication or surgery } \\
\text { (to lower intraocular } \\
\text { pressure } 30 \% \text { ) } v \\
\text { observation in normal } \\
\text { tension glaucoma. } \\
\text { Randomised: } 145 \\
\text { patients } \\
\text { Duration: } 5 \text { years } \\
\text { End point: } \\
\text { deterioration of visual } \\
\text { field or optic disc }\end{array}$ & $\begin{array}{l}\text { Intention to treat } \\
\text { analysis: } 22 \text { of } 66 \\
\text { treated } v 31 \text { of } 79 \\
\text { control patients } \\
\text { reached end point } \\
(\mathrm{P}=0.21 \text {, log rank } \\
\text { test). When censored } \\
\text { for cataracts, } 10 \\
\text { treated } v 29 \text { control } \\
\text { patients reached end } \\
\text { point }(\mathrm{P}=0.0018, \text { log } \\
\text { rank test) }\end{array}$ & $\begin{array}{l}\text { Significant only when } \\
\text { analysis censored for } \\
\text { newly developed } \\
\text { cataracts. Dropout } \\
\text { rate not clear }\end{array}$ \\
\hline
\end{tabular}

improvements in study design, but we had to exclude one of these from the meta-analysis because a true control group was missing (table 2). ${ }^{20}$

Combining the results of the remaining five trials (table 3) in a meta-analysis to estimate overall efficacy of pressure lowering treatment in ocular hypertension showed a beneficial treatment effect (hazard ratio $0.56,95 \%$ confidence interval 0.39 to 0.81 , $\mathrm{P}=0.01$; fig 2). To estimate the hazard ratio of Schulzer et al, ${ }^{7}$ we assumed from the completely overlapping Kaplan-Meier curves a $P$ value of 1.00 (stated as non-significant in the publication). We could not observe significant heterogeneity of the included studies $\left(\chi^{2}=6.2, \mathrm{P}=0.185 ; \mathrm{I}^{2}=35.4 \%, 95 \%\right.$ confidence interval 0 to $75.8 \%)$.

To illustrate the baseline risk, Kaplan-Meier estimates in the control group for remaining free of glaucomatous visual field defects within five years after treatment onset ranged from approximately $63 \%$ to $91 \%$ in the five trials. We therefore used the $80 \%$ mark as a realistic, but conservative assumption to calculate the number needed to treat as an example of absolute effect. When this information and the estimated hazard ratio of 0.56 are used, 12 patients with ocular hypertension alone need to be treated to prevent the first glaucomatous visual field defect or definite glaucomatous disc change within five years of treatment (95\% confidence interval for number needed to treat 9 to 29 ).

\section{Treatment of open angle glaucoma with and without raised intraocular pressure}

Until recently only a very small trial had been conducted ${ }^{21}$ which did not show a significant effect in the treatment group. Because we could not extract data as information on the number of end points was missing, we excluded this study from the analysis (table 2). Table 4 shows a summary of two more recent randomised controlled trials in manifest open angle glaucoma that we included in the analysis. ${ }^{11-13}$ 


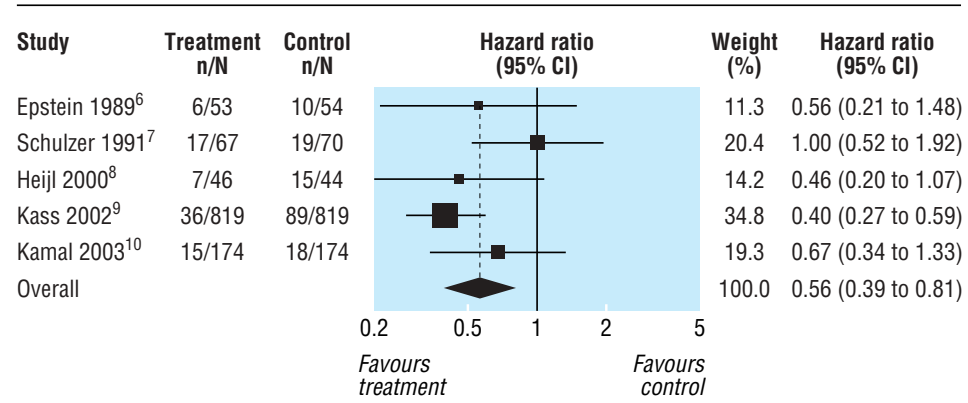

Fig 2 Visual field loss or deterioration of optic disc, or both, among patients randomised to pressure lowering treatment $v$ no treatment in ocular hypertension. Hazard ratios of less than 1.0 favour pressure lowering treatment. Boxed area is proportional to weight given to each trial in the statistical model. Heterogeneity: $\chi^{2}=6.2$ $(P=0.185) ; I^{2}=35.4 \%$ (95\% confidence interval 0 to $\left.75.8 \%\right)$

Combining the results from the early manifest glaucoma trial $^{1112}$ and the Collaborative Normal-Tension Glaucoma Study Group $^{13}$ showed a significant pooled treatment effect of lowering intraocular pressure to effectively prevent glaucoma progression (hazard ratio $0.65,95 \%$ confidence interval 0.49 to 0.87 , $\mathrm{P}=0.003$; fig 3 ). The included studies were not significantly heterogeneous $\left(\chi^{2}=0.13, \mathrm{P}=0.72\right)$.

The Kaplan-Meier estimate in the control group for remaining free of glaucoma progression within five years after treatment onset was $42 \%$ and $43 \%$ in the early manifest glaucoma trial and the Collaborative Normal-Tension Glaucoma Study Group, respectively. Accordingly, when using the $40 \%$ mark and the estimated hazard ratio of 0.65 , seven patients with glaucoma need to be treated to prevent one patient with glaucoma progression within five years of treatment (95\% confidence interval for number needed to treat 4 to 20 ).

\section{Sensitivity and subgroup analysis}

Changing our meta-analysis model from random to fixed effects did not change the results in either meta-analysis. The subgroup of patients with elevated ocular pressure glaucoma responded well to pressure lowering treatment, as seen in a subgroup analysis of these patients in the early manifest glaucoma trial (hazard ratio $0.57,95 \%$ confidence interval 0.37 to $0.89, \mathrm{P}=0.013$; data not presented in a figure). ${ }^{11}{ }^{12}$ However, to investigate whether patients with normal tension glaucoma would fare equally well as all patients with open angle glaucoma patients, we extracted the subset of data from the early manifest glaucoma trial ${ }^{11}{ }^{12}$ accordingly and combined this with the uncensored data set from the collaborative normal-tension glaucoma study. ${ }^{13}$ Although fewer end points were reached in the treatment group (hazard ratio $0.70,95 \%$ confidence interval 0.48 to $1.02, \mathrm{P}=0.06$; fig 3), the confidence interval remained wide, indicating remaining uncertainty about the true treatment effect. However, when we used methods described by Altman and Bland, ${ }^{22}$ to compare these two subgroups we found no significant difference.

\section{Discussion}

Primary prevention of glaucomatous visual field defects in patients with ocular hypertension by using topical pressure lowering agents seems to be effective, as shown in this meta-analysis of five methodologically adequate trials. The overall positive effect, as seen in the ocular hypertension treatment study ${ }^{9}$ remained robust, even when combined with all the other non-significant trials to date.

In comparison, a 1993 meta-analysis of randomised controlled trials by Rossetti et al $^{5}$ identified only three appropriate randomised controlled trials out of a total of 102 trials. $^{6720}$ Although the pooled treatment effect showed a reduced risk for progression to glaucoma (odds ratio 0.75 ), the $95 \%$ confidence interval was wide (0.42 to 1.35 ), indicating that worsening of visual field defects could not be excluded in the intervention group.

The recent ocular hypertension treatment study had to exclude 1692 of 3328 patients screened for inclusion in the study for various reasons. ${ }^{9}$ The overall effectiveness of treatment may therefore be different in real practice. Moreover, the effectiveness of the investigators' treatment strategy in patients with mildly raised intraocular pressure (above $21 \mathrm{~mm} \mathrm{Hg}$, but below $24 \mathrm{~mm}$ $\mathrm{Hg}$ ) remains unanswered.

Until now, only few adequate trials have been completed to address the issue of effective secondary prevention of visual field deterioration with pressure lowering treatment in patients with

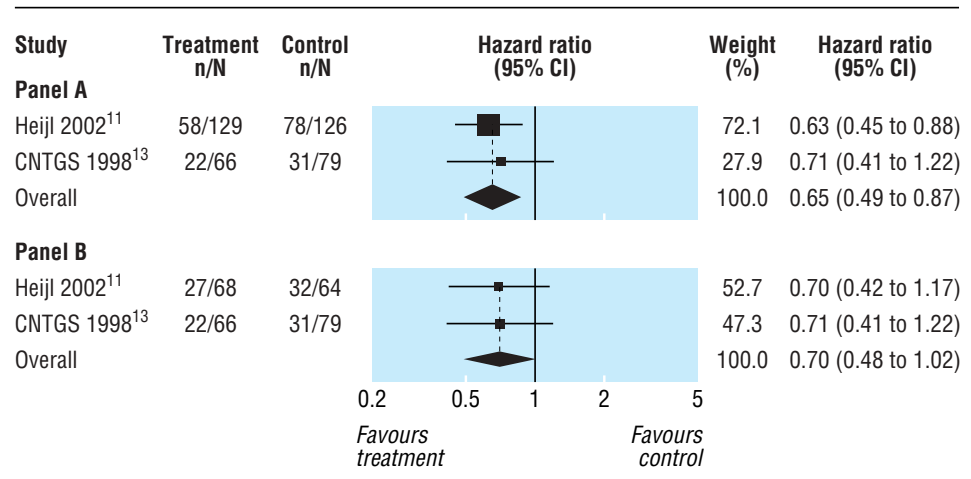

Fig 3 Visual field loss or deterioration of optic disc, or both, among patients randomised to pressure lowering treatment $v$ no treatment in open angle glaucoma (panel A). Panel B shows subgroup analysis of data in normal tension glaucoma. Hazard ratios of less than 1.0 favour pressure lowering treatment. Boxed area is proportional to weight given to each trial in the statistical model. Heterogeneity: $\chi^{2}=0.13(P=0.72)$ for open angle glaucoma and $\chi^{2}=0.001$ ( $\left.P=0.97\right)$ for normal tension glaucoma 
manifest primary open angle glaucoma, most probably because of ethical concerns of including an untreated control group. However, the results of our meta-analysis, as well as the early manifest glaucoma trial, ${ }^{11}{ }^{12}$ show that reducing the intraocular pressure in patients with open angle glaucoma leads to a significant delay of visual field loss, particularly for those patients with increased intraocular pressure, as seen in the subgroup analysis of these patients.

In normal tension glaucoma, lowering the intraocular pressure may be beneficial as seen in the normal tension glaucoma study, ${ }^{13}$ but this has to be confirmed by larger trials and newer treatment modalities, because in this study, the development of excess cases of cataracts may have offset the treatment effect. In addition, we were not able to show a significant treatment effect convincingly when combining the data for patients with normal tension glaucoma in our subgroup analysis. This was mainly due to low power because of the small number of patients with normal tension glaucoma enrolled in these two studies.

\section{Limitations}

Our analysis may have some limitations. Firstly, we cannot fully exclude publication bias; we did not perform a statistical test for the detection of publication bias, since these tests have very low power in meta-analysis of only five trials. However, we did not impose restrictions by language or year of publication, and the search results were complemented by hand searching of relevant journals, yielding more than 1000 reports that we assessed for inclusion in this review. Secondly, since our meta-analysis would lose significance (confidence interval 0.47 to 1.01 ) by excluding the ocular hypertension treatment study, ${ }^{9}$ the overall beneficial effect can only be safely assumed in patients with intraocular pressure of $24 \mathrm{~mm} \mathrm{Hg}$ or more. Four of five included studies on ocular hypertension had high dropout rates, and therefore the magnitude of effect may have been biased.

Although the more recent trials discussed in our report seem methodologically sound, some general questions remain. In particular, it is not entirely clear why some patients may experience disease progression much faster than others (with and without treatment), even if they do not differ in terms of their risk factor profile: The results of the early manifest glaucoma trial ${ }^{11} 12$ showed that the visual fields of many treated patients deteriorated and those of many untreated patients did not. Therefore, more research is needed to identify subgroups that may be particularly susceptible to pressure reduction strategies. Conversely, some patients, especially those with only borderline elevated intraocular pressure or particular genetic traits, may or may not need immediate intervention.

\section{Conclusions}

Although lowering the intraocular pressure in patients with ocular hypertension of $24 \mathrm{~mm} \mathrm{Hg}$ or more to prevent progression to primary open angle glaucoma seems to be beneficial, uncertainty prevails about the optimal treatment for patients with slightly raised intraocular pressure of $22 \mathrm{~mm} \mathrm{Hg}$ or $23 \mathrm{~mm}$ $\mathrm{Hg}$. In general, patients with manifest open angle glaucoma showed a significant delay in progression of visual field deterioration when treated with a pressure lowering strategy. More research is needed in the subgroup of patients without increased intraocular pressure to determine which patients with normal tension glaucoma will benefit most, since our analysis was unable to show a consistent beneficial effect in these patients.

We thank Edith Motschall for her support with the search strategies. Contributors: PCM had the idea for the meta-analysis and participated in conception and design, analysis and interpretation of data, critical appraisal

\section{What is already known on this topic}

Primary open angle glaucoma is a leading cause of blindness in industrialised countries

Lowering intraocular pressure is generally used to prevent and to treat primary open angle glaucoma, although a meta-analysis of trials on ocular hypertension did not show a significant preventive treatment effect

\section{What this study adds}

Medical reduction of ocular pressure seems to be beneficial for the primary prevention of glaucomatous visual field defects

Only one adequate trial has shown effective secondary prevention of visual field deterioration with topical treatment or surgery in patients with manifest primary open angle glaucoma

A meta-analysis summarising data on normal tension glaucoma was inconclusive

of studies, drafting the article, and final approval of the version to be published. He is the guarantor. GS performed statistical analysis of data, revised the article critically for important intellectual content, and gave final approval of the version to be published. JF was involved in interpreting data, revising the article critically for important intellectual content, and giving final approval of the version to be published. GA was involved in interpreting data, revising them critically for important intellectual content, and giving final approval of the version to be published. YTF-Y had the idea for the meta-analysis and participated in conception and design, critical appraisal of studies, revising the article critically for important intellectual content, and giving final approval of the version to be published. Edith Motschall helped with the literature search.

Funding: None.

Competing interests: None declared.

1 Quigley HA. Number of people with glaucoma worldwide. $\mathrm{Br} J$ Ophthalmol 1996;80:389-93

2 Dielemans I, Vingerling JR, Wolfs RC, Hofman A, Grobbee DE, de Jong PT. The prevalence of primary open-angle glaucoma in a population-based study in the Netherlands. The Rotterdam study. Ophthalmology 1994;101:1851-5.

3 Gordon MO, Beiser JA, Brandt JD, Heuer DK, Higginbotham EJ, Johnson CA, et al. The ocular hypertension treatment study: baseline factors that predict the onset of primary open-angle glaucoma. Arch Ophthalmol 2002;120:714-20.

4 Kitazawa Y, Horie T, Aoki S, Suzuki M, Nishioka K. Untreated ocular hypertension. A long-term prospective study. Arch Ophthalmol 1977;95:1180-4.

5 Rossetti L, Marchetti I, Orzalesi N, Scorpiglione N, Torri V, Liberati A. Randomized Rossetti L, Marchetti I, Orzalesi N, Scorpiglione N, Torri V, Liberati A. Randomized
clinical trials on medical treatment of glaucoma. Are they appropriate to guide clinical clinical trials on medical treatment of glauco

6 practice? Arch Ophthalmol 1993;111:96-103. trial of timolol therapy versus no treatment in the management of glaucoma suspects. Ophthalmology 1989;96:1460-7.

7 Schulzer M, Drance SM, Douglas GR. A comparison of treated and untreated glaucoma suspects. Ophthalmology 1991;98:301-7.

8 Heijl A, Bengtsson B. Long-term effects of timolol therapy in ocular hypertension: a double-masked, randomised trial. Graefes Arch Clin Exp Ophthalmol 2000;238:877-83.

9 Kass MA, Heuer DK, Higginbotham EJ, Johnson CA, Keltner JL, Miller JP, et al. The ocular hypertension treatment study: a randomized trial determines that topical ocular hypotensive medication delays or prevents the onset of primary open-angle glaucoma. hypotensive medication delays or $\mathrm{p}$

10 Kamal D, Garway-Heath D, Ruben S, O'Sullivan F, Bunce C, Viswanathan A, et al. Results of the betaxolol versus placebo treatment trial in ocular hypertension. Graefes Arch Clin Exp Ophthalmol 2003;241:196-203

11 Heijl A, Leske MC, Bengtsson B, Hyman L, Hussein M. Reduction of intraocular pressure and glaucoma progression: results from the early manifest glaucoma trial. Arch Ophthalmol 2002;120:1268-79.

12 Leske MC, Heijl A, Hussein M, Bengtsson B, Hyman L, Komaroff E. Factors for glaucoma progression and the effect of treatment: the early manifest glaucoma trial. Arch Ophthalmol 2003;121:48-56.

13 The effectiveness of intraocular pressure reduction in the treatment of normal-tension glaucoma. Collaborative Normal-Tension Glaucoma Study Group. Am J Ophthalmol 1998; 126:498-505.

14 Parmar MK, Torri V, Stewart L. Extracting summary statistics to perform meta-analyses of the published literature for survival endpoints. Stat Med 1998;17:2815-34.

15 Ihaka RG, Gentlemen R. "R": a language for data analysis and graphics.J Computational Graphical Stat 1996;5:299-314. 
16 Higgins JP, Thompson SG, Deeks JJ, Altman DG. Measuring inconsistency in meta-analyses. BMJ 2003;327:557-60.

17 Altman DG, Andersen PK. Calculating the number needed to treat for trials where the outcome is time to an event. BMJ 1999;319:1492-5.

18 Shin DH, Kolker AE, Kass MA, Kaback MB, Becker B. Long-term epinephrine therapy of ocular hypertension. Arch Ophthalmol 1976;94:2059-60.

19 Kitazawa Y. Prophylactic therapy of ocular hypertension. A prospective study. Trans Ophthalmol Soc N Z 1981;33:30-2.

20 Kass MA, Gordon MO, Hoff MR, Parkinson JM, Kolker AE, Hart WM, Jr., et al. Topical timolol administration reduces the incidence of glaucomatous damage in ocular hypertensive individuals. A randomized, double-masked, long-term clinical trial. Arch Ophthalmol 1989:107:1590-8.

21 Holmin C, Thorburn W, Krakau CE. Treatment versus no treatment in chronic open angle glaucoma. Acta Ophthalmol (Copenh) 1988;66:170-3.

22 Altman DG, Bland JM. Interaction revisited: the difference between two estimates. BMJ 2003;326:219.

(Accepted 27 May 2005) doi 10.1136/bmj.38506.594977.E0

Department of Ophthalmology, University Hospital Freiburg, Killianstr 5, D-79106 Freiburg, Germany

Philip C Maier fellow in ophthalmology

Jens Funk professor of ophthalmology

Institute of Medical Biometry and Medical Informatics, University Hospital Freiburg

Guido Schwarzer senior statistician

Gerd Antes director, German Cochrane Centre

Louis Stokes VA Medical Center, Case Western Reserve University, 10701 East Blvd, Cleveland, OH 44106, USA

Yngve T Falck-Ytter assistant professor of medicine

Correspondence to: P Maier maierphi@aug.ukl.uni-freiburg.de 